\title{
Ecojustice, equity and ethics: challenges for educational and career guidance
}

\author{
Ecojusticia, equidad y ética: retos para la orientación educativa y \\ profesional
}

\author{
Barrie A. Irving \\ Edinburgh Napier University \\ Beatriz Malik-Liévano \\ UNED
}

Recibido: 06/11/2019

Aceptado: 25/11/2019

\begin{abstract}
In social and environmental terms we live in precarious and uncertain times, where not only the sustainability of the planet rests in the balance, but also that of human existence. Many nation-states around the world talk of the importance of social cohesion, and are aware of the threat of environmental degradation, climate change, and ecological well-being. However, the dominating global policy discourse, particularly championed in the West, is located within a delimiting neo/liberal political framework. With a few noticeable exceptions, the influence of neo/liberal thinking continues to flourish in the contemporary career literature where there has been little deep critical engagement with the discourse of capitalist economics and how these impact human and environmental well-being. Often caught up in market-led discourses, and captured by the notion that 'work sets you free', educational and career guidance has been located within an uncritical economic frame. Its energies tend to be directed towards the preparation of individuals to make 'good' educational and occupational choices, underpinned by the need for 'clients' to acquire the skills and competencies demanded by employers (and the economy) (Bengtsson, 2011; Irving, 2018). The disjuncture between educational and career guidance and social and environmental justice (i.e. ecojustice) has rarely been breached. In this article, we seek to disrupt dominant discourses of the market that currently permeates thinking in education by identifying how an ecojustice perspective provides a forward looking and equitable foundation for educational and career guidance.

KEY WORDS: Ecojustice, equity, neoliberal discourse, educational guidance, career education, career guidance, sustainability.
\end{abstract}

\section{RESUMEN}

En términos sociales y ambientales, vivimos en tiempos precarios e inciertos, donde no solo la sostenibilidad del planeta está en juego, sino también la de la existencia humana. Muchos estados-nación de todo el mundo hablan de la importancia de la cohesión social y son conscientes de la degradación ambiental, el cambio climático y la amenaza al bienestar ecológico y social. Sin embargo, el discurso dominante de la política global, particularmente defendido en Occidente, se sitúa dentro de un marco político neoliberal. Con algunas notables excepciones, la influencia del pensamiento neoliberal continúa siendo hegemónico en el campo de la educación y de la orientación profesional, donde en términos generales ha habido poco compromiso crítico profundo con el discurso de la economía capitalista y cómo este impacta sobre el bienestar humano y ambiental. A menudo atrapada en discursos dirigidos por el mercado y por la noción de que "el trabajo nos hace libres", la orientación educativa y profesional se ha ubicado dentro de un marco económico acrítico. Se tiende a preparar a los individuos para tomar "buenas" decisiones educativas y ocupacionales, respaldadas por la necesidad de que adquieran las habilidades y competencias exigidas por los empleadores (y la economía) (Bengtsson, 2011; Irving, 2018). La disyuntiva entre la orientación educativa y profesional y la justicia social y ambiental (la ecojusticia) rara vez se ha abordado. En este artículo cuestionamos los discursos dominantes del mercado que actualmente impregnan el pensamiento en educación, y proponemos la adopción de una perspectiva de ecojusticia que proporciona una guía para el futuro y contribuye a promover la equidad desde la orientación educativa y profesional.

PALABRAS CLAVE: Ecojusticia; equidad; discurso neoliberal; orientación educativa; educación para la carrera; orientación profesional; sostenibilidad.

Autor de correspondencia 


\section{Challenging language and changing perspectives: shifting the discursive boundaries}

We live in precarious and challenging times, characterised by an uncertain future for humankind due to the effects of climate change and the growth in inequality between individuals and nations (OECD, 2011; OXFAM, 2019). As Griffiths and Murray (2017) note, "The planet seems to be heading into an ecological catastrophe [where] the earth will become uninhabitable . . At the same time, we humans are beset by appalling injustices, both locally and globally, and across cultures" (p. 39). Hence there is a need to think critically about the future, talk productively about the inherent relationship between environmental and social justice, and act positively to effect meaningful change (Porritt, 2005). This requires us to disrupt the discourses of economic profit (and prophets) that dominate in contemporary society.

\subsection{Dominant discourse and given truths: language games at play}

Language is never neutral or devoid of deeper meaning. Its use is saturated with particular social, cultural and ideological beliefs, and can serve to transmit and normalise representations of the 'real world'. Hill and Tulloch (2015), referring to the work of Gramsci, comment,

language works by stealth because it is the medium of understanding. It disappears as 'language' [and thus becomes discourse] as it consolidates into understanding and knowledge. The stability of the assumptions harboured in normative language act to entice us to think no further than within the boundaries of our existing cultural and historical reasoning (p. 149).

Discourse is not restricted to language alone: pictorial representations, signs, and symbols can also normalise particular perspectives; nevertheless, language use might be regarded as the most common and forceful means of communication. Through conversation, for example, our individual subjectivity and consciousness is co-constructed (Richardson, 2009) as we make sense of who I am/we are. In other words, our understanding of 'self' in the world, and how our/the world is structured, does not come from within, but is constructed through everyday talk and text which informs how we give meaning (and meaning is given) to our experiences, and to the experiences of those around us. Discourse thus operates in complex and subtle ways. Embedded as part of the wider social fabric, discourse not only creates the discursive conditions through which the world might be understood, it is also part of an interactive social process in which individuals ascribe meaning to the/their world, and can influence, shape, and delimit thought, imagination, and action.

Dominant discourse is embedded within existing structures of power, where it is utilised to "frame representations of 'how the world is', present socially constructed 'truths' as incontrovertible, and establish 'common-sense' explanations and solutions" (Irving, 2013a, p. 187). Here, the voices of those social groups that are the most powerful and influential are privileged (Colley, 2000; Hill \& Boxley). Hence, as Alvesson and Skoldberg (2009) have succinctly highlighted, "Social structures and material conditions mean that discourses and language give expression to particular power relations, and lock people into various forms of subjectivity" (p. 195). As a result of constant re/articulation via the media, by way of official channels (such as political announcements or policy documents), and through everyday text and talk, such discourses become normalised, embedded within the general psyche as 'accepted truths'. Through this process, they act to shape social reality (Alvesson \& Karreman, 2000) and limit the range of subject positions (i.e. choices/identities) made available. This discursive play facilitates the construction of a particular normative representation of reality and narrative, such as the primacy of corporate capitalism as the only feasible social order, through which we come to learn who I am/we are, what can/cannot be said, and who I/we might become, and where I/we 'fit', alongside versions of what is deemed to be possible in the future. This permeates educational discourses and practices, and unless they adopt a critical stance, it is easy for teachers and guidance counsellors to act in accordance with this narrative. 
1.2. Disrupting the discourses of economic profit (and prophets): challenging times

Dominant neo/liberal discourse is centred on notions of economic growth and development and the importance of wealth creation, where individual responsibility and corporate rights are reified over collective well-being. Guided by reports produced by organisations such as the World Bank and the OECD, the focus of education and career guidance tends to be directed towards the preparation of individuals to make 'good' educational and occupational choices, underpinned by the need for 'clients' to acquire the skills and competencies demanded by employers (and the economy) (Bengtsson, 2011; Irving, 2018). Equity, in relation to social and environmental justice, thus tends to be positioned as subservient to the pursuit of economic development, where the focus rests on capital accumulation and growth, labour market requirements and the commodification of the individual. Within neoliberalism, collective well-being in relation to the provision of a living wage or the payment of unconditional welfare support for example, or engagement in activities that challenge the hegemonic discourses of capitalism, consumerism, and excess consumption, are positioned as disruptive and detrimental. Here, discussion about what constitutes 'meaningful careers', 'productive lives', and active citizenship, tends to be located within an individualised market context.

To take this discussion further, the following examples illustrate a range of dominant discourses that are positioned as 'common-sense' realities. Yet for each of the 'truths' presented, there are also questions to be asked and/or counter discourses that can be brought into play (Irving, 2013b):

- Without economic growth there can be no development. Questions here relate to who determines the kind of economic growth advocated for; what kind of development is expected to ensue, what are the ecological and human costs of economic development, and what alternative forms of development might replace models based on economic growth.

- The pursuit of profit provides life purpose. This highlights the value accorded to 'profit' and economic accumulation within capitalism. Yet, for example, should the profit motive be regarded as the primary purpose of human existence; what are the ethical dimensions of 'winning' and 'losing' in the race for profit; does this commodify the individual to one in which they are positioned as a socio-economic 'asset' or 'liability'.

- Those not engaged in 'productive labour' (i.e. paid employment) are at risk of social exclusion. The narrow boundaries constructed around social inclusion actively excludes many groups from appropriate recognition and social participation, and reduces the human value of those who are not economically active, whether through choice or circumstance.

- Career identity and personal fulfilment is intertwined with labour market participation. Career is understood in a reductive way. This raises questions around the extent to which career discourse can be regarded as 'holistic'. Associating the language of personal fulfilment with labour market participation reinforces this further.

- Competition, and the drive to succeed, is healthy for the individual, the economy, and society. Competition is reified, and a particular understanding of 'individualised drive' is implied and presented as beneficial. Success, at any cost perhaps, is most highly vaunted. Yet how else might 'success' be measured? What does this say about collaboration and co-operation, and how does this position those who might be regarded as 'weak', or unwilling to compete.

- Sustainability, and social responsibility, drives contemporary corporate development and practice. The 'greening' of products, and seeing corporations accept a semblance of social responsibility, 
has a certain allure. Yet, whilst such a discourse appears positive on the surface, it could be employed as part of a 'greenwashing' strategy, utilised as a clever marketing ploy to appeal to a 'consumer's sense of virtuousness'. Moreover, the practice of corporate social responsibility can be used to deflect attention away from many organisations' primary purpose which is profit maximisation in their own best interests (Fleming \& Jones, 2013).

\subsection{Pushing back: traversing traditional boundaries}

Although a neoliberal worldview is currently embedded within much career discourse, this does not mean that there is no hope of change. Marglin (2010) observes that those economists who advocate market solutions to social (and environmental) problems promote a view that destabilises a healthy and caring society through attempts to "make community invisible" (p.4), thus contributing to its ultimate destruction. Hence the truth claims of neoliberal economic 'prophets' that capitalism operates in the community's interests must be challenged, and notions of economic growth and development must be reframed. However, this will require us to think, talk, and act differently. For example, this requires us to think differently about what constitutes 'profit' and the multiple forms this might take; to reflect more carefully on which 'prophets' we heed; and to explore more equitable ways in which 'profit' might be generated, managed, and utilised in the collective interests of all people and the planet as we enter an era of increasingly scarce resources (Cato, 2012). Hence, we do not have to accept the logic of capitalism in which "a person is measured according to their ability to access and accumulate capital" (Hill \& Tulloch, 2013, p. 147) positioning them as economic assets or liabilities. Consequently, if such discourses are to be shifted it will require us to find the discursive spaces to expose 'taken-for-granted' explanations, to disrupt dominant accounts of 'what happens', and 'what is possible', in the 'real world', and to more vociferously articulate future possibilities. Engaging more productively with the language of ecology and justice (ecojustice), and adjusting our educational and career guidance practices accordingly, can thus contribute to a meaningful discursive shift that will have long-term sustainable benefits for us all.

As career professionals (and concerned citizens), if we are to shift dominant discourses, such as the apparent 'rightness' of the economic order, it will require us to question many of the 'commonsense' explanations that have become part of the everyday tapestry of social life. As these discourses have been constructed in particular self-interested ways, we need to consider how these can be actively subverted, with alternative discourses inserted. From a green perspective, for example, this will require us to challenge the language of economic profits, and neoliberal prophets such as Hayek and Friedman (see Stedman Jones, 2014), who promote a (supposedly) free-market economy, and elevate the value of individual capital accumulation above the collective well-being of people and the planet. Thus, we need to develop a language, and facilitate practice, that undermines the foundations of neoliberalism and questions the individualistic and inequitable workings of capitalism. We believe that the adoption of an ecojustice philosophy will provide us with the ethical foundations to achieve this.

\section{Towards a green alternative: an ecojustice perspective}

Far from being a manifestation of 'left wing diatribe' or a latter form of Luddism, the adoption of an ecojustice perspective has powerful support. The 2019 climate change protests by millions of young people around the world (SBS, 2019), and the assertive stance of the 16 year old activist Greta Thunberg who berated world leaders for their failure to acknowledge climate emergency (The Guardian, 2019) signals a desire for real change. Moreover, as Thunberg argued, there is a need to move away from preoccupations with "money and fairy tales of eternal economic growth" (The Guardian, 2019) if humankind, and the planet, are to thrive. In many respects this is echoed by the World Council of Churches (2019) who 
contend, in their website, that "In linking environmental and social justice issues, the environmental approach, 'ecojustice in short', challenges both humanity's destruction of the earth and the abuse of economic and political power which result in poor people having to suffer the effects of environmental damage". This position connects with the more pithy ecofeminist standpoint, which, identify Bloodheart and Swim (2010) "theorizes that hegemonic systems of power and oppression materialize both as domination of men over women and as domination of people over the environment leading to degradation of the ecosystems" (p.187).

\subsection{Defining moments: ecojustice in context}

As a counter discourse that is focused on meaningful sustainability in relation to human and environmental well-being, an ecojustice philosophy challenges neoliberalism by moving away from masculinist discourses of competition, economic growth and development. It rejects neoliberal preconceptions of the selfish individual', and challenges the practices of hyper-consumerism. Briefly, ecojustice can be seen to encompass:

- A discourse of care: for the well-being of the environment, the planet, and all living creatures;

- A practice of tolerance and compassion: for ourselves and each other in local, national and global contexts;

- Sustainable ways of seeing and knowing, being and belonging, talking and acting: the establishment of a commons in which individuals relate to, and engage with, each other in thoughtful, respectful, creative and participative ways that actively include, rather than exclude, the voices of marginalised and indigenous groups;

- Cooperation and collaboration rather than competition and greed: where there is an equitable sharing of the world's resources, accompanied by an acceptance that 'we' are all in this together, therefore necessitating immediate and long-term social and environmental improvements.

It is important to add that the ecojustice perspective connects the local with the global, where both state-based and global framing of social and environmental concerns are regarded as intertwined rather than unique (Martin, 2013). This is particularly salient when the gaze is turned towards the potential of the so-called underdeveloped world.

\subsection{Ecojustice: a foundation for educational and career guidance}

Career is a contested concept, shaped in multiple ways by economic, social and political discourses. Hence, the individual and collective meaning-making that occurs as part of the educational and career guidance process is contingent on the discourses that are made available. These discourses inform concepts of 'self, 'work', 'opportunity', 'justice', 'choice', 'inclusion', and 'good citizenship'. Here, dominant discourses can seek to define what forms of 'career' are deemed to be socially, politically and economically acceptable, and delimit the contexts in which career is discussed.

There is, of course, some value in ensuring that individuals acquire the skills, knowledge and competencies to enable them to make 'good' educational and occupational choices, and gain an awareness of the needs of employers and demands of the economy. Nevertheless, we contend that this should be regarded only as one possible dimension of career if it is not to become reductionist. Hence, there is a need to broaden the career discourse, taking it beyond the confines of occupational choice, or the notion that meaningful career enactment (that can lead to self-fulfilment and wellbeing) must be contingent on labour market engagement. A more holistic view acknowledges that life and career are intertwined (Coutinho, Dam \& Blustein, 2008; Richardson, 2009). Here, acknowledgement is given to the idea that meaningful life-careers can also be constructed and pursued outside of paid work. This might include those who give meaning to their life-career through 
pursuit of personal interests (such as hobbies, sports, educational courses), being a homemaker, or activities that directly challenge the hegemonic practices of capitalism (through environmental activism or as members of anti-capitalist movements for instance). Hence, constructing, having and enacting a career is not automatically economically quantifiable here, but a signifier of the complex ways in which lives play out, and can also have environmental and social justice implications.

Jucker (2004) thus poses an interesting question, which is pertinent to those engaged in educational and career guidance, when he asks "how can we achieve the best possible life - not the highest possible living standard but the best quality of life - for the greatest number of people within the Earth's limits?" (p. 15). When career is viewed as a social construction, where it is better understood as a metaphorical rather than a fixed term, opportunities are presented which allow for a deeper, critical, and more nuanced engagement. For instance, some consideration has been given to issues of social in/justice, the pervasive influence of neoliberal discourse, and the workings of oppression and domination in the contemporary educational and career guidance literature (see for example, Hooley, Sultana \& Thomsen, 2018, 2019; Irving 2011; Irving \& Malik, 2005). However, on the rare occasions where discussion about the impact of a changing environment on career construction, choice, and enactment has occurred, this been characterised by a somewhat reductive focus on the encouragement of young people in particular to look to the 'green jobs' of the future if they are to secure sustainable employment, drawing a veil over deeper ecojustice issues. For example, the production of goods through the application of environmentally friendly manufacturing processes to feed the desires of an artificially contrived and externally managed market does little to address issues of over-consumption and the 'short-termism' of a throw-away society centred on image and self at the expense of social equity and community well-being. Furthermore, looking at occupations and the labour market in isolation of ecojustice concerns fails to effectively deepen critical understanding of the deleterious effects of discrimination, the inequitable distribution of wealth, and the restricted access to life-giving resources brought about through capitalist practices.

This highlights the importance of providing young people and adults with a wide range of discursive positions that allows them to critique, examine, and explore what might be meant by 'meaningful careers'. Enabling them to determine how they wish to construct and enact their career, and locating this within an ecojustice framework, contributes to a critical discursive engagement about the possible future 'self, their communities, and the planet. If career discourse is to align with an ecojustice perspective, it will require career theorists, researchers and professionals to pay closer attention to the complexities of social and environmental justice and to extend the discursive resources available for all to draw upon. At a theoretical level, for instance, career discourse needs to move beyond an uncritical acceptance of the notion that paid work sets you free, and is fundamental to mental health and self-fulfilment. Educational and career guidance, in all of its guises, will thus need to be part of an ongoing critical social process that enables people to engage with, and manage, multi-locational and open-ended life-careers that may be subject to revision or rejection at different points in time.

\subsection{Locating the ethical dimensions of ecojustice: constructing 'citizen green'}

So what might citizen green look like within an ecojustice ethical context? Basically, ethics is about doing the right thing (Mautner, 1997), where it is connected to the morals and values which shape "the principles, norms, and standards of conduct governing an individual or group" (Trevino \& Nelson, 2011, p. 17). Thus, ethics is concerned with how we order the/our world, how we decide to lead our lives, and what concerns we prioritise. Taking a holistic ecojustice stance, the ethical characteristics of green citizenship is thus embedded within a global context where the common good is privileged, underpinned by an active moral engagement with issues of equity and socially just change (Mason, 2013). Here, "global injustice and global citizenship are intricately linked to issues such as global warming, availability of water, clean air, and the oil [and fossil fuel] economy, all of which affect everyone but which are disproportionately caused by the rich and suffered by the poor" 
(Griffiths \& Murray, 2017). Thus, the pursuit of ecojustice needs to become a fundamental part of the individual and collective human condition, and embedded within democratic and participative processes. This is especially salient for those working within the sphere of educational and career guidance.

As discussed throughout this article, to be 'green' is not simply about environmental sustainability, it also requires a commitment to social justice, equity, and fairness. This will require 'green citizens' to engage in a constant interrogation, reassessment, and renegotiation of what is required if an ethically sound ecojustice present, and future, is to be secured. This will require a reflexive exploration of the past, a critical examination of the present, the construction of potential future scenarios, and the development of strategies through which this might be achieved. Thus, whilst it means that we must all learn to live with uncertainty, and embrace a dynamic and fluid present, this should be welcomed as a sustainable future is not represented by a fixed end-point.

\section{Ecojustice in practice: an educational and career guidance imperative}

Educational and career guidance operates in an inherently political arena (Watts, 2006), and can either contribute to, or challenge, oppression and domination (Irving, 2011). Thus, it is crucial to acknowledge that our interventions can never be truly 'impartial' or 'value free'. Therefore, our credibility as career professionals may be enhanced if we are more open about our " ... personal beliefs systems that underpin [our] practice" (Bosley, Arnold \& Cohen, 2007, p. 132). We must also think more deeply and critically about whose interests we serve, and whose should be paramount, what it is we should be seeking to achieve for the individual and society, and what contribution we can make in relation to an ecojustice future, and present. Hence, this requires us to decide where we stand in relation to ecojustice, both personally and professionally, and how, or whether, we intend it to inform our practices. As a consequence, this may require us to engage as social activists (Irving \& Marris, 2002) who seek to disrupt the illusion that 'all will be well' if we simply enable young people to make uncritical career decisions that are shaped by the economic demands of the moment.

\subsection{New horizons: ecojustice in practice}

"If students learn to engage enough with the world to develop informed, critical, heartfelt judgements, a pedagogy is required that inspires, persuades, and encourages them to pay attention and rethink their outlooks on the world ... [and] make engaged connections with it" (Griffiths \& Murray, 2017, p.45)

The education of career teachers and practitioners might seek to engage in activities that ensure "the students we send forth into the world are equipped with the knowledge, skills and sensitivities to become ecologically virtuous citizens" (Cato, 2012, p. 1034).

If educational and career guidance is to take up the ecojustice challenge it will require new theorising supported by ecojustice-focused research, and the insertion of critical and creative approaches that engage with ecojustice issues in practice.

"EcoJustice Education" is shaped by an understanding that local and global ecosystems are essential to all life; challenging the deep cultural assumptions underlying modern thinking that undermine those systems; and the recognition of the need to restore the cultural and environmental commons (Martusewicz, Edmundson, \& Lupinacci, 2015).

Those of us who are active in the education and career arena, whether as academics, policy makers or practitioners, should not consider ourselves to be helpless victims of global capitalism who no longer have a voice, as a result of demands for the career 'industry' to demonstrate its economic value, at the expense of wider concerns with fairness, justice and well-being. As Irving argued, "whilst career educators and counsellors may be subject to the discourses of the state, they do not necessarily need to be ensnared by the rhetoric" (Irving, 2005, p. 21). Yet this will demand courage and resilience. 
Through career counselling opportunities we could actively engage 'clients' in a reflexive examination of the social and environmental impact of their vocational choices. We could publicise, support, and advocate for the inclusion of alternative choices to those made available within the formal economy through our career practices. As a result, such choices have a greater chance of becoming normalised, accepted, and viewed as being acceptable. Such alternatives might range from being active in the informal economy, participating as an activist with social and/or environmental rights groups, developing a self-sufficient lifestyle, or becoming a homemaker.

We could locate career development activities within a broader context that encompasses a collective 'green-justice' perspective. Through this, who 'I' want to be/become, takes on a deeper significance as it is built on relationships both in terms of 'others', and the needs of the planet. It will also help raise awareness of what might be influencing the choices that are made available.

Through career education, we could construct critical learning opportunities that enable participants to identify and engage in issues related to social, political, economic and environmental concerns (locally and globally). These can be used to envisage and explore 'green' futures, whilst identifying how connects can be made with notions of social justice.

As Morrow and Torres (2002) identify, "transformative action can be carried out only by participants who construct their own collective learning process as part of changing their relationship to the social world" (p. 16).

Within an educational context, Jones (2006) identifies that critical reflection, which is a key component of transformative learning, "encourages students to reflect not just on the content of the subject but on their own personal process of learning and coming to know" (p. 376).

Educational and career guidance cannot operate in isolation of the socio-political and ecological environment, and thus may not be regarded as neutral or impartial. For example, how often do we ask our clients to explore and reflect on the ways in which different career choice(s) might contribute to, or potentially detract from, social well-being and impact on the welfare of the planet? From an ecojustice standpoint, therefore, we contend that the role of educational and career guidance must be about raising awareness and facilitating a critical understanding amongst our clients of the possible implications of their choices, thus contributing to fully informed decisions.

\section{Conclusions: Where to from here?}

It would be facile to suggest that the pursuit of an equitable and sustainable future for all humanity and the planet is not without its challenges, particularly within a career education and guidance context. However, whilst it may not be easy being an ecojustice advocate in the current economic climate, looking at all forms of educational and career guidance through an ecojustice lens will help to accentuate the complex and embedded relationship between self, community, society and environment. Acknowledging that those engaged in educational and career guidance may not necessarily be in a position to directly change inequitable labour market practices, or alleviate unemployment (Plant, 1999; Roberts, 2005), this should not be seen to render us as powerless. We need to begin by recognising that we are not merely cogs in a neoliberal wheel (often unwittingly perhaps) or unthinking state agents. Nor should we position ourselves as hapless (or helpless) victims of a global market discourse that has commoditised and commodified careers work, judging its contribution and value against its economic utility (Irving, 2005; Mcllveen \& Patton, 2006). To engage in a discursive movement for change will demand courage and resilience, and is not without risk.

A more holistic view of career education and guidance that not only works to improve the life of individuals, but also acknowledges its wider social responsibilities, is an essential prerequisite. This will require career professionals to become social activists (Irving \& Marris 2002), moving beyond the relative safety of the school, college or counselling situation to expose and challenge social injustices within the wider community. By openly taking a critical stance as career educators and counselors it will help to clarify our role in relation to choice and opportunity, and reassure those for 
whom we have a responsibility to educate, inform and guide that we are working in the interests of both individuals and groups to secure just futures (Irving \& Malik, 2005), and a fair and environmentally friendly society.

Clearly, there is scope for us, as education and career professionals, to be transgressive, and open up guidance and learning to transformative discourses that provide opportunities to envisage positive futures that are built on ecojustice foundations. For example, we have explored how the adoption of a transformative approach towards learning (and guidance) provides the tools that will assist us, and our clients, to think deeply about our world, talk differently the challenges the future poses more productively, and inform all of our actions accordingly. Hence, all of us in the careers community (academic, researcher and practitioner alike) must be prepared to critically reflect on the nature of our theories, review our priorities, and re/examine our practices by viewing the implications of our work through an ecojustice lens. Making meaningful connections between careers work and ecojustice is essential if, through our educational and career guidance practices, we are to contribute to the advancement of lives worth living in a world worth living in.

\section{Referencias bibliográficas}

Alveson, M. \& Karreman, D. (2000). Varieties of discourse: On the study of organizations through discourse analysis. Human Relations, 53(9), 1125-1149. DOI: https://doi.org/ $10.1177 / 0018726700539002$.

Alveson, M. \& Skoldberg, K. (2009). Reflexive methodology: New vistas for qualitative research (second edition). London: Sage

Bengtsson, A. (2011). European policy of career guidance: the interrelationship between career selfmanagement and production of human capital in the knowledge economy. Policy Futures in Education, 9(5), 616-627. doi: 10.2304/pfie.2011.9.5.616

Bosley, S., Arnold, J. \& Cohen, L. (2007). The anatomy of credibility: A conceptual framework of valued career helper attributes. Journal of Vocational Behavior, 70, 116-134. DOI: https://doi.org/ 10.1016/j.jvb.2006.07.003.

Bloodheart, B. \& Swim, J. K. (2010). Equality, harmony, and the environment: An ecofeminist approach to understanding the role of cultural values in the treatment of women and nature. Ecopsychology, 2(3), 187-194. doi: 10.1089/eco2010.0057

Cato, M. S. (2012). Green economics: putting the planet and politics back into economics. Cambridge Journal of Economics, 36, 1033-1049. doi: 10.1093/cje/bes022

Colley, H. (2000). Deconstructing 'realism' in career planning: how globalisation impacts on vocational guidance. In Institute of Career Guidance (Ed.), Career Guidance: Constructing the Future. A global perspective. (pp. 11-29). Strourbridge, England: Institute of Career Guidance.

Coutinho, M.T., Dam, U.C. \& Blustein, D.L. (2008). The psychology of working and globalisation: a new perspective for a new era. International Journal for Educational and Vocational Guidance, 8, 5-18. doi: 10.1007/s10775-007-9132-6

Fleming, P. \& Jones, M. T. (2013). The end of corporate social responsibility: Crisis and critique. London: Sage.

Griffiths, M. \& Murray, R. (2017). Love and social justice in learning for sustainability. Ethics and Education 12(1), 39-50. doi: 10.1080/17449642.2016.1272177

Hill, D. \& Boxley, S. (2007). Critical teacher education for economic, environmental and social justice: An ecosocial manifesto. Journal for Critical Education Policy Studies, 5. Retrieved from: https://bit.ly/2rCa8XL.

Hill, D. \& Tulloch, L (2013). Can market capitalism be greened? Environmental education revisited. Policy Futures in Education, 11(2), 142-153. doi org/10.234/pfie.2013.11.2.145:

Hooley, T., Sultana, R. G., \& Thomsen, R. (2018) (Eds.), Career Guidance for Social Justice: Contesting Neoliberalism. Oxon, England: Routledge. 
Hooley, T., Sultana, R. G., \& Thomsen, R. (2019) (Eds.). Career guidance for emancipation: Reclaiming justice for the multitude (pp. 183-199). Oxon, England: Routledge.

Irving, B. A. (2005). Social justice: a context for career education and guidance. In B. A. Irving and B. Malik (eds.), Critical reflections on career education and guidance: promoting social justice in a global economy (pp. 10-24). London, England: RoutledgeFalmer.

Irving, B. A. (2011). Career education as a site of oppression and domination: an engaging myth or a critical reality? Australian Journal of Career Development, 20(3), 24-30. DOI: https://doi.org/ $10.1177 / 103841621102000305$.

Irving, B. A. (2013a). Discourses of delusion in demanding times: a critical analysis of the career education and guidance policy guidelines for New Zealand secondary schools. Qualitative Research Journal, 13(2), 187-195. doi: 10/1108/QRV-03-2013-0019

Irving, B. A. (2013b). "It's not easy being green" - re/positioning ethical values in career practice. Paper presented at the LAEVG Conference: Career counselling: A buman or a citizen's right?, within the Symposium: 'Green guidance': A time for action. Montpellier, France. September 2013. Unpublished.

Irving, B. A. (2018). The pervasive influence of neoliberalism on policy guidance discourses in career/education: Delimiting the boundaries of social justice in New Zealand. In T. Hooley, R. G. Sultana, and R. Thomsen (2018) (Eds.), Career Guidance for Social Justice: Contesting Neoliberalism (pp. 47-62). Oxon, England: Routledge.

Irving, B.A. \& Marris, L. (2002). A context for connexions: Towards an inclusive framework' in Institute of Career Guidance (ed.) Career Guidance: constructing the future. Social inclusion: policy and practice, Stourbridge: Institute of Career Guidance.

Irving, B. A. \& Malik, B. (2005). Introduction. In B. A. Irving and B. Malik (eds.), Critical reflections on career education and guidance: promoting social justice in a global economy, pp. 2-9. London, England: Routledge Falmer.

Jones, P. (2006). Considering the environment in social work education: Transformations for ecosocial justice. Australian Journal of Adult Learning, 46(3), 364-382.

Jucker, R. (2004). Have the cake and eat it: Ecojustice versus development? Is it possible to reconcile social and economic equity, ecological sustainability, and human development? Some implications for ecojustice education. Educational Studies, 36(1), 10-26. doi: 10.1207/s15326993es3601_3

Marglin, S. (2010). The dismal science: how thinking like an economist undermines community. Cambridge, MA: Harvard University Press.

Martin, A. (Ed.), 2013. Global environmental in/justice, in practice: introduction. Geographical Journal 179(2), 98-104. doi: 10.1111/geoj.12021

Martusewicz, R. A., Edmundson, J., \& Lupinacci, J. (2015). Toward diverse, democratic, and sustainable communities (2nd Edition). New York, NY: Routledge.

Mason, K. (2013). Becoming citizen green: prefigurative politics, autonomous geographies, and hoping against hope. Environmental Politics 13, 1-19. doi: 10.1080.09644016.2013.775725

Mautner, T. (1997). The penguin dictionary of philosophy. London, England: Penguin.

McIlveen, P. \& Patton, M. (2006). A critical reflection on career development. International Journal for Educational and Vocational Guidance, 6, 15-27. doi: 10.1007/s10775-006-0005-1

Morrow, R. \& Torres, C. (2002). Reading Freire and Habermas: critical pedagogy and transformative social change. New York, NY: Teachers College Press.

Organisation for Economic Cooperation and Development (2011). Divided we stand: why inequality keeps rising. Paris, France: OECD

Oxfam Briefing Paper (January 2019). Public good or private wealth? Oxford, England: Oxfam GB. Retrieved from: https://bit.ly/36ATGFW.

Plant, P. (1999). Fringe focus: informal economy and green career development. Journal of Employment Counseling, 36, 131-140. https://bit.ly/36ATGFW

Porritt, J. (2005). Capitalism: As if the world matters. London, England: Earthscan.

Richardson, M. S. (2009). Another way to think about the work we do: Counseling for work and relationship. International Journal for Educational and Vocational Guidance, 9(2), 75-84. doi: 10.1007/s10775-009-9154-3 
Roberts, K. (2005). Social class, opportunity structure and career guidance. In B. A. Irving and B. Malik (Eds.), Critical reflections on career education and guidance: promoting social justice in a global economy, pp.130-142. London, England: RoutledgeFalmer.

SBS News (2019). Millions protest across the world in youth led climate strike. Retrieved from: https://bit.ly/2RV3uXk.

Stedman Jones, D. (2014). Masters of the Universe: Hayek, Friedman, and the Birth of Neoliberal Politics. Princeton, NJ: Princeton University Press

The Guardian (September, 2019). Greta Thunberg condemns world leaders in emotional speech at UN. Retrieved from: https://bit.ly/35jqByx.

Trevino, L. K. \& Nelson, K. E. (2011). Managing business ethics: Straight talk about how to do it right (fifth edition). Hoboken, NJ: Wiley.

Watts, A. G. (2006). Socio-political ideologies in guidance. In A. G. Watts, B. Law, J. Killeen, J. Kidd and R. Hawthorne (Eds.). Retbinking career education and guidance: Theory, policy and practice (pp. 351365). London, England: Routledge.

World Council of Churches (2019). What we do. Retrieved from: https://bit.ly/2Pn6sCd.

Para citar este artículo

Irving, B. A , \& Malik-Liévano, B. (2019). Ecojustice, equity and ethics: challenges for educational and career guidance. Revista Fuentes, 21(2), 253-263. [Fecha de consulta: dd/mm/aa]. doi: 10.12795/revistafuentes.2019.v21.11.09 